\title{
Successful eradication of the European rabbit (Oryctolagus cuniculus) and house mouse (Mus musculus) from the island of Selvagem Grande (Macaronesian archipelago), in the Eastern Atlantic
}

\author{
Paulo OLIVERA, ${ }^{1}$ Dilia MENEZES, ${ }^{1}$ Roger TROUT, ${ }^{2}$ Alan BUCKLE,${ }^{3}$ Pedro GERALDES ${ }^{1}$ and José \\ JESUS $^{4}$ \\ ${ }^{1}$ Parque Natural da Madeira, Quinta do Bom Sucesso, Caminho do Meio, Madeira, ${ }^{2}$ Forest Research, Alice Holt Lodge, Farnham, \\ Surrey, ${ }^{3}$ School of Biological Sciences, The University of Reading, Reading, UK and ${ }^{4}$ University of Madeira, Department of Biology, \\ Campus of Penteada, Portugal
}

\begin{abstract}
The Portuguese island of Selvagem Grande (Great Salvage) in Macaronesia is an important seabird breeding station in the eastern Atlantic. Significant populations of Cory's shearwater Calonectris diomedea (Scopoli, 1769), Bulwer's petrel Bulweria bulweria (Jardine \& Selby, 1828) and little shearwater Puffinus assimilis baroli (Bonaparte, 1857) are present, and white-faced storm-petrel Pelagodroma marina (Latham, 1790) and Madeiran storm-petrel Oceanodroma castro (Harcourt, 1851) populations are of global significance. Selvagem Grande also provides diverse habitats for an extensive flora, including 11 endemic species. The 270-ha island was also inhabited by two alien invasive mammals: the European rabbit Oryctolagus cuniculus (Linnaeus, 1758) and the house mouse Mus musculus (Linnaeus, 1758). Both are known to have had adverse impacts on breeding seabirds and island vegetation. In 2002, the Natural Park of Madeira conducted a program using brodifacoum bait formulations aimed at rabbit and mouse eradication. Approximately 17000 individual baiting points were established on a $12.5 \times 12.5 \mathrm{~m}$ grid. Baits were also applied by hand "seeding" on steep slopes and cliffs where bait stations could not be placed. Rabbits were removed after a month. However, mice persisted for considerably longer and strategic bait applications against them continued for a further six months. Subsequent assessments by trapping, bait takes and systematic observation of signs over three years, has confirmed the removal of both alien invasive species. This paper presents information on these operations, on measures adopted to mitigate adverse impacts of the eradication program on important vertebrate non-target species, including Berthelot's pipit Anthus berthelotii Bolle, 1862 and a species of gecko Tarentola bischoffi Joger, 1984 and on the initial response of the island's ecosystem to the eradication of rabbits and mice.
\end{abstract}

Key words: alien invasive, island restoration, Mus musculus, non-target mitigation, Oryctolagus cuniculus.

Correspondence: Paulo Oliveira, Parque Natural da Madeira,

Quinta do Bom Sucesso, Caminho do Meio, 9050-251, Funchal,

Madeira, Portugal.

Email: paulooliveira.sra@gov-madeira.pt

\section{INTRODUCTION}

The Ilhas Selvagens consist of a sub-archipelago of the three Portuguese Salvage Islands (Selvagem Grande, 
Selvagem Pequena and Ilhéu de Fora), and several other islets, lying in the eastern Atlantic $\left(30^{\circ} 10^{\prime} \mathrm{N}, 16^{\circ} 20^{\prime} \mathrm{W}\right)$ $300 \mathrm{~km}$ from the mainland of Madeira and $150 \mathrm{~km}$ from the Canary Islands.

The Portuguese explorer Diego Gomes reportedly discovered the islands in 1460. As a result of a conjugation of various factors, in particular their geographical location, isolation and difficult conditions for plant and animal colonization, the islands support unique ecosystems of high biodiversity value. Under the administration of the Natural Park Service of Madeira (Serviço do Parque Natural da Madeira), they are protected under Portuguese Law as a Strict Nature Reserve. The islands are also protected under European Commission legislation, being included within the Natura 2000 Network (European Commission 2007) as a Site of Community Interest and a Special Protection Area. Birdlife International also classifies the islands as an Important Bird Area (Grimmett \& Jones 1989; Costa et al.2003).

Selvagem Grande is the largest island in the group. The island, of volcanic origin and supporting an arid ecosystem, has a plan area of approximately 245 ha and a surface area of approximately $270 \mathrm{ha}$. The main topographical feature is an undulating plateau of roughly 150 ha, part of which is sandy and much burrowed by seabirds. The island's coastline is mostly composed of steep to very steep rocky slopes and there are extensive sea cliffs in the north, which rise to a height of approximately $100 \mathrm{~m}$ and make up about onequarter of the island's coast.

Selvagem Grande provides varied terrestrial habitats of significant ecological value but is probably most noted as an important breeding station for five species of pelagic seabirds (Oliveira \& Menezes 2004). All these are considered Species of European Conservation Concern (SPEC), varying in their conservation status (for details refer to Burfield \& van Bommel 2004). The most numerous species is the white-faced storm-petrel Pelagodroma marina, estimated at 36000 pairs (Campos \& Granadeiro 1999) (SPEC 3: Vulnerable). Cory's shearwater (Calonectris diomedea), estimated at 30000 pairs, is the second most abundant and probably the biggest colony in the world (Granadeiro et al. 2006) (SPEC 2: Vulnerable). According to Menezes et al. (2004) other species populations are smaller, with Bulwer's petrel (Bulweria bulweria) at 4000 pairs (SPEC 3: Rare), little shearwater (Puffinus assimilis baroli) at 2700 pairs (SPEC 3: Rare) and Madeiran storm-petrel (Oceanodroma castro) at 1500 pairs (SPEC 3: Rare).

The only breeding land bird present is the nominate subspecies of Berthelot's pipit (Anthus bertheloti bertheloti), with a population of approximately 100 breed- ing pairs. The other native vertebrate species present in Selvagens are an endemic species of gecko Tarentola bischoffi and an endemic subspecies of lizard Teira dugesii selvagensis (Bischoff, Osenegg \& Mayer, 1989) (Arnold et al. 2007).

The Selvagens group of islands provides habitats for approximately 111 xerophytic plant species, including 11 that are endemic to the islands (Press \& Short 1994). This represents the highest percentage of endemics per land surface area in the entire Macaronesian Region. Most of the endemics are recorded on Selvagem Pequena and Ilhéu de Fora, where there are no records of introduced plant and animal species (Neves et al. 1995).

Several plant and animal species were introduced to Selvagem Grande as a result of human activity. Among the plant species, tree tobacco Nicotiana glauca Graham is highly invasive and was present at a high density throughout the island until management began in 2000 . The impact of this plant upon the natural ecosystems of islands and continental areas where it has been introduced is widely described (e.g. Sanz-Elorza et al. 2001; Florentine \& Westbrooke 2005; Gray et al. 2005).

The three species of alien mammals, the European rabbit Oryctolagus cuniculus Linnaeus, 1758, the house mouse (Mus musculus) and the domestic goat Capra hircus Linnaeus, 1758, once present on Selvagem Grande, all are listed among the "One Hundred of the World's Worst Invasive Alien Species" by the Invasive Species Specialist Group of the World Conservation Union (Lowe et al. 2000). The provenance of these mammal populations can only be speculated upon. Long (2003) reports the introduction of house mice to Madeira to have occurred in approximately 1420 and it might be that their establishment on Selvagem Grande was also ancient. The same author provides information on the introduction of rabbits and goats to many of the islands of the Madeiran archipelago, which mostly took place in the 15th and 16th centuries, but mentions nothing about their introduction to Selvagem Grande. Goats were extinct on the latter island by the beginning of the 20th century.

Rabbits have been released on at least 800 islands worldwide (Flux \& Fullager 1992). This adaptable species is renowned for damaging the environments it inhabits by causing reduction of vegetation cover, resulting in loss of species diversity and reduction in habitat quality (Lockley 1976). These lead to deterioration of, or increased competition for, the critical resources of food, shelter and protection from predators for other species (Bailey 1956; Ely \& Clapp 1973; Merton 1987; Flux 1994). Increased erosion from wind or precipitation might also occur, including loss 
of areas with burrow nesting birds (e.g. Pterodroma feae (Salvadori, 1899) on Bugio Island [Birdlife International 2007]). Additionally, rabbits might provide a "prey buffer" for (introduced) predators, allowing hyper-predation on native species, such as seabirds (Courchamp et al. 2003). Rabbits dig burrows faster than seabirds and might compete with burrow nesting seabirds for breeding sites. They could be expected also to disturb, and possibly damage, the eggs and chicks of birds when they enter occupied burrows (Sheail 1971). There is little firm evidence of direct impacts of rabbits on nesting seabirds, although Brown (1975) observed the destruction of tern eggs by rabbits.

The severe adverse impacts of rats, mainly Norway rats Rattus norvegicus (Berkenhout, 1769) and roof rats Rattus rattus (Linnaeus, 1758), on breeding seabirds are well documented (see e.g. Courchamp et al. 2003; Igual et al. 2006) and programs for the eradication of rats from islands are commonly carried out (Veitch \& Clout 2002). Until recently, mouse predation was not considered to pose a serious threat to seabirds (Atkinson 1985) and very little conservation effort has been put into their removal from islands (Wanless et al. 2007). However, Cuthbert and Hilton (2004) report predation by house mice of two species of seabirds on Gough Island, Atlantic petrels Pterodroma incerta (Schlegel, 1863) and Tristan albatrosses Diomedea dabbenena Brooke, 2004, and population modeling has revealed a potential for this predation to cause population decline (Wanless et al. 2007). Other authors have documented the impacts of mouse populations on birds (Blight et al. 1999; Drever et al. 2000), and direct observations of predation by mice on newly-hatched Bulwer's petrels and white-faced storm-petrel petrels on Selvagem Grande have been made by these authors.

Recognizing the potential adverse impacts of the alien vertebrates on the island's animal and plant communities, and as a part of ongoing efforts by the Natural Park Service of Madeira to improve the conservation value of the Nature Reserves under its jurisdiction, a program of work was started in 2002 with the aim of the removal of rabbit and mouse populations from Selvagem Grande. The removal of these species was also intended to support the nomination, by the Portuguese Government, of the Ilhas Selvagens Nature Reserve as a World Heritage Site. The present paper provides information on the planning and implementation of the vertebrate eradication program, mitigation measures carried out to reduce the adverse impacts of rodenticide applications on non-target animals and a preliminary assessment of the benefits to the island's fauna and flora of the successful eradication event.

\section{MATERIALS AND METHODS}

\section{Planning}

Project planning consisted of a feasibility study, a series of risk assessments and the identification of field logistical procedures, together with establishing necessary agreements with appropriate government departments of the Autonomous Region of Madeira and the Portuguese Navy. Assessments of the different components of risk included optimizing the availability of each target mammal species to effective control and, conversely, identifying non-target species at risk of harm from the baiting operations: especially those at significant risk. The duration of the main baiting operation, mode of bait delivery and both direct and indirect mitigation measures for nontarget species were considered, including opportunities to reduce the likelihood of adverse effects by timing, location and types of bait. The fact that some of the terrain to be baited contained bird burrows in soft sand, making in inaccessible during the breeding period of the species involved, was a particular difficulty. The considerations resulted in the choice of pellets containing $0.002 \%$ brodifacoum "Pestoff 20R" as the main bait to be used, supplemented when necessary by other appropriate products containing brodifacoum. A draft plan and environmental risk assessment were produced, and subsequently modified by agreement as changing field situations required. It was considered that both rabbits and mice could be made fully at risk and accessible by hand baiting, so the use of other methods for rabbits, such as shooting, were not considered cost effective until required for "mopping up" remnants.

Transport logistics were an important parameter because the island was so remote and its terrain so steep that it was not practicable to use planes or helicopters. A 4.5-m inflatable boat was used to deliver all food, water, materials and to land up to 10 personnel from the Portuguese naval patrol boat that visited the island every three weeks as part of other duties. Bait was packed and delivered from the manufacturer in robust 10-kg plastic buckets, which were ideal for safe handling and storage during the long transportation process. After landing ashore, the bait, an "All Terrain Vehicle" and six tons of diverse materials (marker flags, bait tubes and construction material) were winched $100 \mathrm{~m}$ up from the landing site to the island's plateau. Bait was stored either in a cave or small stone building reconstructed for this purpose and was not kept in the open for more than a few days because of the effect of the sun. Buckets of bait were distributed in bulk across the island along transects so as to be easily available from 
Figure 1 Map showing main topographical features of Selvagem Grande, including watercourses, triangulation pillars and contour lines at $25 \mathrm{~m}$ intervals. The $1 \times 1$ ha grid is superimposed which formed the main axes for bait laying and other monitoring operations.

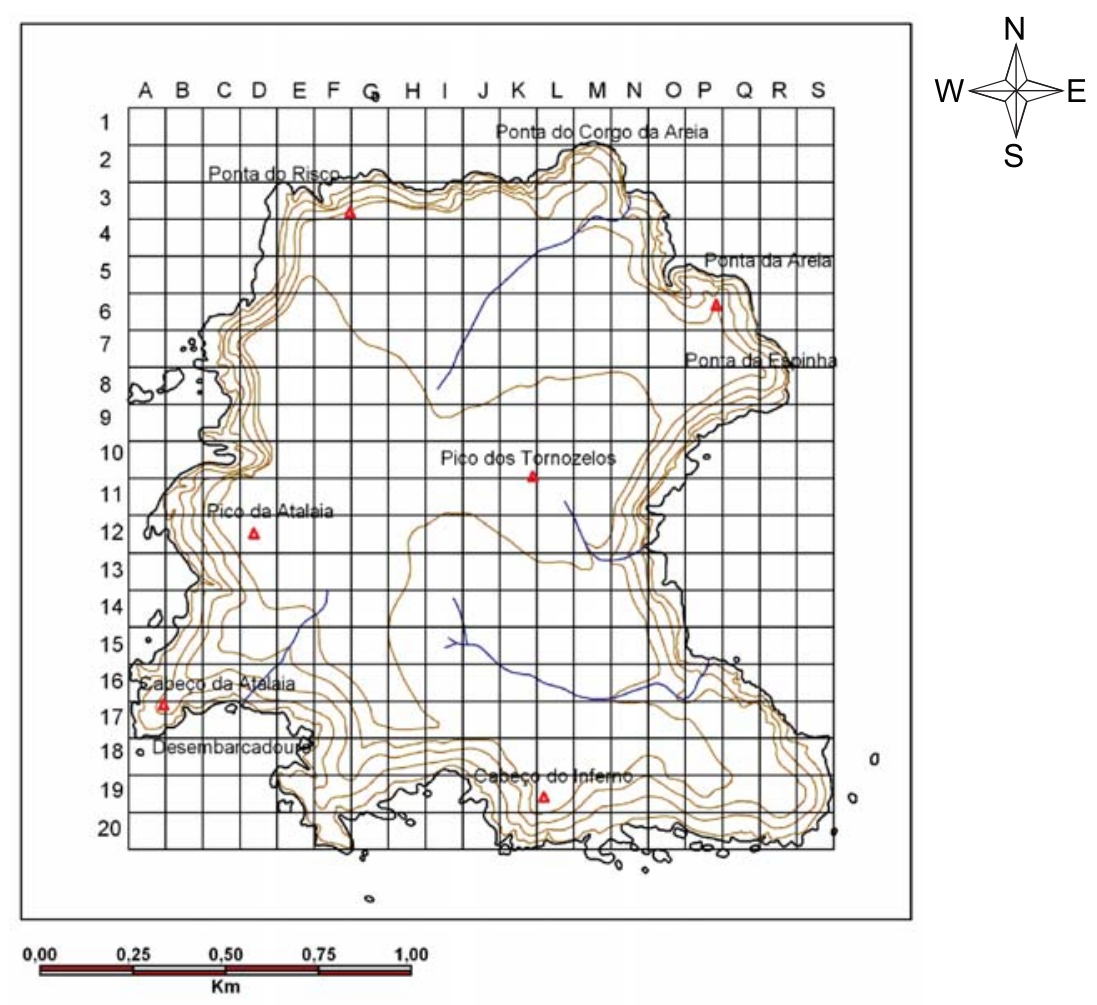

these caches during the baiting process.

\section{Field preparation}

Before the baiting operation began, staff of the Natural Park Service of Madeira used polythene canes to grid the island into 1-ha units using the Global Positioning System (GPS), and a flag with a unique identification number was positioned at the corner of each (Fig. 1). The exceptions to this process were the cliffs and steeper slopes where paint spots were used instead. This allowed accurate positional reporting of any information onto a master map available for staff to update daily. Bait tubes (80-100 mm diameter plastic "Tubex," $0.4 \mathrm{~m}$ long) were fixed first at 25 -m intervals $\left(16 \mathrm{ha}^{-1}\right)$, then progressively increased to a density of $12.5-\mathrm{m}$ intervals $\left(64 \mathrm{ha}^{-1}\right)$. For the $2.5 \mathrm{~km}$ of cliffs, rope attachment points were drilled in advance of the baiting operation so climbers could progress rapidly. Target and non-target species monitoring was initiated as outlined below and continued beyond the end of the eradication phase.

\section{Baiting strategy}

The bait laying consisted of three phases. A first period of bait distribution and laying occurred between the 8th and the 20th of August 2002, involving a team of 9-10 people working exclusively on this task. For operational and safety reasons the baiting team was split into two groups: while one baited the plateau, the other baited the cliffs and steeper slopes. Bait was measured out using standardized containers as 150 or 200 -gm placements, according to previously conducted mouse and rabbit population density assessments. It was laid on a grid of $12.5 \times$ $12.5 \mathrm{~m}$ and placed either in the tubes or in piles directly on the ground. Flimsy plastic rodent bait trays were tried but quickly broke up and blew away. On stony screes and steep areas, bait was mostly spread out by hand, but some piles were left at $25-\mathrm{m}$ intervals to allow for subsequent bait take assessments. Baiting was conducted systematically, and progressed around the island in an anti-clockwise direction. The two baiting teams moved synchronously so as to avoid leaving any unbaited areas behind them. The entire baiting process is estimated to have comprised approximately 16500 individual bait placements and approximately $180 \mathrm{~km}$ of transect lines were traversed.

The second phase began immediately after completion of the first. The entire island was covered again, in the same sequence, to examine bait takes and top up bait points 
where necessary. This procedure took place approximately three weeks after the initial laying of bait at any one site. In this phase, specific attention was paid to areas considered to be ideal mouse habitat, such as rock walls, holes, stony scree slopes, edges of cliffs, areas with thick vegetation and bird nesting holes that might have been missed by the grid baiting. These areas were baited "strategically, " in other words independent of the $12.5 \times 12.5 \mathrm{~m}$ grid. Simultaneously, eight rabbit traps were placed near rabbit latrines in the few areas where recent evidence of rabbit activity was seen.

As a result of the observed adverse impact of the bating operation on the Berthelot's pipit population, any open bait piles were removed and replaced by tubes in those parts of the plateau where bird densities were highest and mortalities had been found. To continue to make bait available to mice and for monitoring purposes, more tubes were positioned at $12.5 \mathrm{~m}$, concentrating initially on large rocky boulder slopes and sandy areas with many sea bird burrows, and where trapping indicated mice were still present.

The third phase started prior the onset of winter and ended in early spring and employed three to five people. In this phase, the pellet bait was removed and replaced in every tube with wax blocks containing $0.005 \%$ brodifacoum (either 20-g Talon Wax Blocks or 5-g Klerat Wax Blocks) as they provided more resistance to rain. Between the end of September 2002 and the end of March 2003, mouse tubes replaced open bait points for $100 \mathrm{~m}$ around any bait point found with mouse activity. Eventually, the only area where bait tubes were not placed was the vertical cliff on the north of island. In total, approximately 16000 bait tubes were used.

In early spring 2003, the whole island was traversed again, the bait tubes were inspected and bait was strategically placed in the areas where mouse activity was suspected.

\section{Monitoring of rabbits and mice}

\section{Before bait laying operations}

Between April and July 2002, before bait laying operations began, daytime surveys of rabbits were conducted (i.e. observations of presence of rabbit feces, scrapes/ burrows or live rabbits) to confirm that rabbits utilized the whole island. Night-counts, each of 2-h duration on each of three transects, were made to confirm rabbit activity and to assess relative population densities. Live trapping was carried out to study body and reproductive condition.

During July and August 2002, mice were live-trapped using 50 Longworth traps. Tapping lasted for four nights on each of seven 1-ha grids to obtain an assessment of the mouse population densities, using the cumulative nightly number of new individuals captured. Autopsies of the last samples of mice were carried out to determine their body condition and breeding activity.

\section{During and after bait-laying operations}

Bait consumption from bait piles and tubes was inspected on a rolling program that took two to three weeks in order to complete all baiting points. Grid squares with heavy bait takes were recorded and the bait was topped up if $75 \%$ or more of it had been removed.

One month after the beginning of the first phase of baiting, pieces of carrot were placed in bait tubes and mouse activity was assessed by the presence or absence of tooth-marks. However, there was some difficulty with this procedure because insects, snails and lizards were occasionally observed feeding on the carrot and abraded any sharp edges. Rabbit monitoring consisted of walking the previously-used transects, casual observation of carcasses and the location of malodorous bodies in rock cavities during other operations, although these operations were required for less than two months. During winter $2002 / 2003$, any mouse tooth-marks on a wax block bait triggered the immediate provision of tubes and fresh bait covering an area of 1 ha centered on that location.

After the conclusion of the main baiting phases, three baited live trapping grids, each covering 1 ha and using 50 Longworth mouse traps and/or "Trip-traps" (a lightweight plastic live-capture trap) for three nights, were used simultaneously and virtually continuously. Grids were initially concentrated on two areas with known or suspected remaining mice but were distributed across the whole island after May 2003. During 30 months from January 2003July 2005 a total of 60000 trap nights were conducted.

\section{Monitoring vegetation and non-target species}

The techniques of monitoring vegetational changes and the populations of non-target species, and subsequent treatment of the data obtained, were designed to be straightforward and simple to allow them to be replicated easily in future by different staff members of the Natural Park Service of Madeira.

\section{Vegetation}

Eight locations were identified by GPS in autumn 2002 and fixed point photography was initiated. Photography has been conducted at these locations at regular intervals and will continue for the foreseeable future. A total of 
eight permanent $10 \times 10 \mathrm{~m}$ vegetation quadrats were assessed, covering a representative range of habitats across the island, for species composition, frequency of occurrence and percentage plant cover. Species composition and groundcover data were analyzed for significant differences by the Wilcoxon test for matched pairs. In addition, records were made of the locations and size of rare plants when they were found in various parts of the island.

\section{Invertebrates}

The relative abundance and taxonomic diversity of invertebrates was monitored in the same eight quadrats used for monitoring vegetational changes. Invertebrate sampling consisted of direct collection, either by hand or with fine forceps for the smaller specimens. This monitoring was carried out within three bands, each of $10 \times 1 \mathrm{~m}$, inside each of the eight quadrats.

Because of the taxonomic complexity of these samples, the material was identified to family level and was sent to specialists for further specific identification. For purposes of monitoring changes in the invertebrate fauna, groups within the Order Coleoptera were selected to provide an index of invertebrate abundance and diversity. These taxons were chosen because of their direct involvement with the vegetation and because they were commonly taken as food by non-target species. Family composition was analyzed using the Friedman test for significant changes over time.

\section{Reptile monitoring}

The abundance of the lizard $T$. dugesii selvagensis was not specifically monitored because the species was not considered to be at unacceptable risk as a result of previous experience using brodifacoum baits on the Madeiran island of Deserta Grande, and also because its very high numbers. Due to the lack of information on the direct/ indirect effect of the bait upon the gecko (T. bischoffi), their high conservation value and lower population density, they were classified as a priority non-target species. A monitoring scheme was implemented involving recording the numbers of geckos found inside 15 quadrats each of $100 \mathrm{~m} \times 100 \mathrm{~m}$ by two observers searching carefully for 30 min under the most probable stones, which were immediately carefully replaced. This was done both before and after the main baiting operations and repeated every spring until spring 2006. A number of individuals were also kept in captivity as a mitigation measure against catastrophic population decline (see below).

\section{Land birds (Berthelot's pipit)}

The density and distribution of Berthelot's pipit populations were monitored in four transects, each of $800 \mathrm{~m}$, covering a wide range of the island's habitats. These transects were walked at a predetermined speed by one observer, who recorded all the birds seen or heard. Pipits were also captured by mist-netting, ringed and monitored individually during bait laying operations. Several different mitigation actions were also implemented (see below).

\section{Seabirds}

No monitoring of numbers and breeding success of the island's seabird populations was undertaken during the work reported in the present paper. This is because populations of these species, in particular Cory's shearwater and white-faced storm petrel, are the subject of ongoing studies by other authors (Campos \& Granadeiro 1999; Granadeiro et al. 2006; Zino et al. 2008) which might be used to assess impacts on these populations.

\section{Mitigation to reduce adverse impacts on non- target species}

The initial risk assessment procedure indicated several vertebrate species to be at significant risk of an operation involving hand baiting. The risks involved both physical disturbance by human activity of breeding bird populations and potential primary and secondary effects of the biocide used. One way to mitigate the damaging effects of the operation was to choose a time window for the largescale baiting activity when the species at risk were absent from the island. This had to be set, however, in context of a requirement for the operation to be effective; in particular that individuals of the target species were all at a high risk of taking bait because of the limited availability of alternative food. Ultimately, compromise was required because no available time window was completely satisfactory, mainly due to the fact that the principal species at risk were present on the island at different times of year. The main baiting period was set for late AugustOctober. The species of highest concern had preventative mitigation measures implemented and were also monitored before, during and after the bait laying operations alongside other monitoring described above.

\section{Seabirds}

Only one seabird species was susceptible to being disturbed heavily by the bait-laying operation during the period chosen, the white-faced storm petrel. An estimated 15000 pairs were breeding in holes excavated in soft sandy 
soils on the island's plateau and many were in the final stage of fledging during the first phase of bait laying. To avoid disturbance of the colony, a delay in bait application of two weeks was instigated in the area of the breeding burrows. For the entire operation, a minimum number of transect routes and grid lines were made through this area and all movement kept to them to reduce damage to burrows. Additionally, bait piles were put on the tracks, bait was hand-broadcast from them and was laid inside many holes with the help of long plastic tubes.

\section{Geckos}

During the main period of bait laying operations, 110 geckos were kept in captivity. They were enclosed in $0.6 \times$ $0.4 \mathrm{~m}$. terrariums, where their natural habitat was simulated; each terrarium harbored two to four individuals. Every three days, larvae of mealworms (Tenebrionidae) were provided as food.

\section{Berthelot's pipit}

Several different measures where taken to mitigate the effects of the baiting on the small population of Berthelot's pipit. Initially, an attempt was made to keep as many birds as possible in captivity. Two different types of aviary were constructed: small individual cages of $1 \times 1 \times 1 \mathrm{~m}$ and a large communal structure of $50 \times 50 \times 2 \mathrm{~m}$. However, although some individuals adapted successfully to these cages, mist-netted birds failed to adapt to captivity and this strategy was abandoned. Two other contingency measures were implemented. First, the anticoagulant antidote (vitamin $\mathrm{K}_{2}$, Kanakion) was made available in 12 drinking places on raised platforms, distributed throughout the plateau. These were especially designed to be attractive to the birds but not accessible to rabbits and mice. Second, a small number of birds were captured, ringed and held temporarily at Selvagem Pequena, a nearby island located $22 \mathrm{~km}$ away. The species had been reported in this island before and conditions were considered adequate for the survival of the translocated individuals.

\section{RESULTS}

\section{Monitoring of rabbits and mice}

\section{Rabbits}

Pre-baiting night-counts of rabbits and dung pile (latrine) surveys confirmed a relatively low level of rabbit activity in all areas of the island. Autopsy of captured rabbits confirmed no current breeding activity but a high level of white fat deposits, almost covering the kidneys, was observed in all individuals. This indicated that the rabbit population was in good condition and under little or no food stress.

Observations of rabbit activity carried out during the baiting program showed a rapid decline in rabbit numbers. The last live rabbit was seen on a night transect at the beginning of the second week of September 2002, approxi-

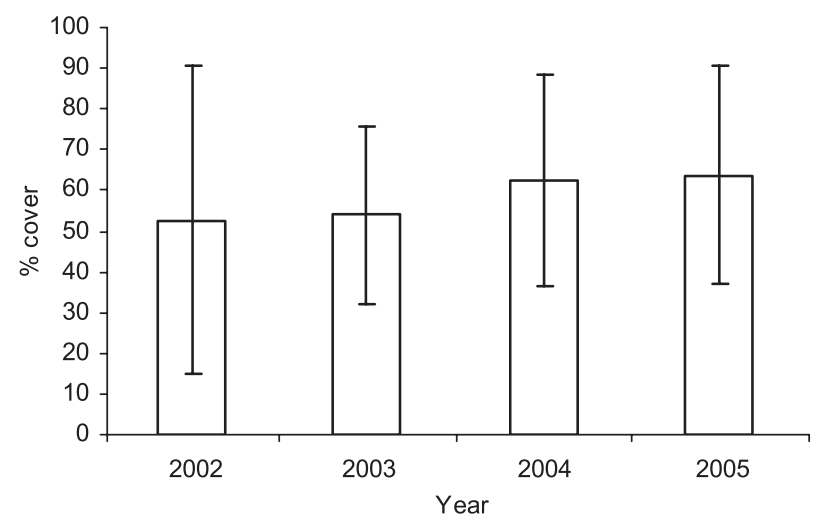

Figure 2 Results of monitoring vegetation cover in eight permanent $10 \times 10 \mathrm{~m}$ quadrats distributed across Selvagem Grande. Histograms show annual mean percentage cover, with standard deviations, for the eight quadrats in the year 2002 (pre-eradication) and for three years after the eradication.

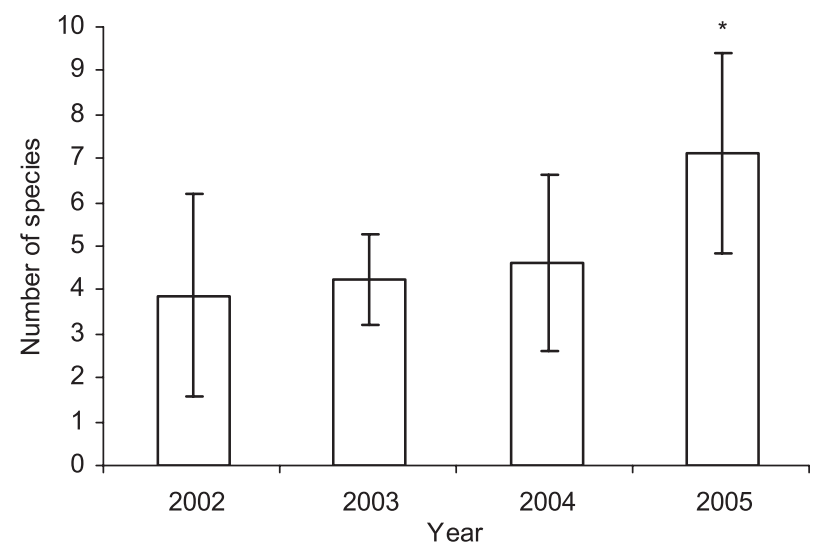

Figure 3 Results of counts of the number of plant species in eight permanent $10 \times 10 \mathrm{~m}$ quadrats distributed across Selvagem Grande. Histograms show annual mean number of species found, with standard deviations, for the eight quadrats in the year 2002 (pre-eradication) and for three years after the eradication. *Refers to a statistically significant increase between the mean number of species found in 2005 when compared to the number found in 2002 . 
mately three weeks after the start of baiting. After this date no more evidence of live rabbits was found, even at bait points using fresh carrot bait that were distributed throughout the island. Regular observations were carried until the end of March 2003, but no further activity was observed.

\section{Mice}

Live-trapping of house mice on grids distributed across the island indicated mouse densities in the range 50-325 mice $\mathrm{ha}^{-1}$ : a sixfold variation in population density. Autopsy of captured mice confirmed the population was breeding, with $60 \%$ of female mice either pregnant or lactating. However, female mice had no fat deposits and were generally in poor body condition.

Monitoring for the presence of mice by inspection of gnawing on fresh carrot bait showed that mice were still present in across much of the island at the end of September 2002, although in low numbers. This was corroborated by the numbers taken in live-capture traps during that month; only seven mice were taken in 1000 trap-nights. Although the last mouse live-capture was in the first week of October 2002, signs of mice (i.e. tooth-marks on bait blocks and carrot baits) were recorded, with a high degree of confidence, in bait tubes until March 2003. It was extremely difficult, however, to be absolutely sure that signs were made by mice, because several other animals were using the bait, including lizards, beetles, snails and ants. In case of reasonable doubt, a positive check was made by setting traps and laying new bait.

A further intensive inspection of the island for mouse activity was conducted using live-trapping (approximately
1600 trap-nights) and bait block monitoring in November 2003. No mouse was caught and no sign of mice was seen anywhere on the island.

\section{Resources used}

The overall project had an estimated cost of 400000 euros. This estimate is based on the assumption that of all manpower expended during operations on the island between 2002 and $200580 \%$ was allocated to the project (approximately 150000 euros). The estimate does not include resources expended as part of regular operations on the island, including the Naval patrol boat (visiting approximately every three weeks) and routine wardening activity. Other costs, totaling approximately 250000 euros, relate to bait purchase and transportation; infrastructure construction/maintenance; mechanical, climbing and recording equipment; boat trips (other than the patrol boat); consultants' and managers' time when not on the island; and staff training. Table 1 presents the breakdown of expenses allocated to the project during the period 20022005.

Between 2002 and 2005 it is estimated that the project used approximately $2630 \mathrm{man} /$ days directly in the field, excluding the time of consultants and managers. Table 2 presents the annual breakdown of manpower resources expended on the major project operations.

A total of $6000 \mathrm{~kg}$ of Pestoff 20R and $400 \mathrm{~kg}$ of Vertox pellet bait was transported to the island and 4500 and 200 $\mathrm{kg}$, respectively, was used during the bait laying operations. The amount of Talon and Klerat wax blocks used was approximately $750 \mathrm{~kg}$, bringing the total amount of bait applied during the program to approximately 5450
Figure 4 Results of counts of the numbers of individuals belonging to four common coleopteran families in eight permanent $10 \times 10 \mathrm{~m}$ quadrats distributed across Selvagem Grande. Histograms show annual mean number of individuals of each family, with standard deviations, for the eight quadrats in the year 2002 (pre-eradication) and for three years after the eradication. ${ }^{*}$ Refers to overall significant increases between 2002 and 2005 for two families.

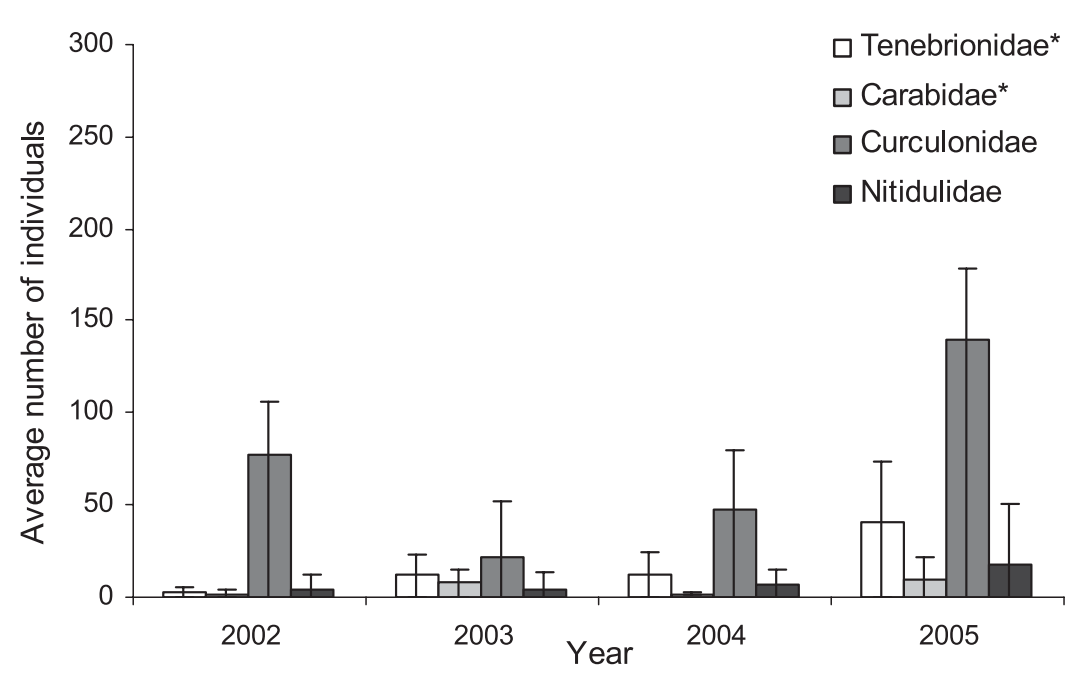


Table 1 Breakdown of costs during the four years of the project, involving preparatory work (P), bait laying (B) and monitoring (M). The annual expenditure on personnel and other costs is expressed as the percentage of the total spent on each of these items for the entire project. The overall cost of the project was estimated to be 400000 euros

\begin{tabular}{llll}
\hline Year & Activities & Personnel (\%) & Other costs (\%) \\
\hline 2002 & P,B,M & 45 & 71 \\
2003 & B,M & 32 & 10 \\
2004 & M & 13 & 10 \\
2005 & M & 10 & 9 \\
\hline
\end{tabular}

$\mathrm{kg}$ or $20 \mathrm{~kg} \mathrm{ha}^{-1}$.

\section{Results of mitigation actions carried out to reduce the impact on non-target species}

All the geckos kept in captivity survived. Each individual was released at the place it was captured.

Berthelot's pipits failed to adapt to captivity. The drinking platforms were seen to be used soon after being placed in the field, although their success in preventing anticoagulant toxicosis in the birds could not be determined. The birds translocated to Selvagem Pequena survived and they were regularly seen on that island. The last ringed bird to be seen was in the summer of 2006. Birds were not taken back to Selvagem Grande because of the rapid recovery of the population there and because the high rate of survival of translocated birds showed that they adapted very well to conditions on Selvagem Pequena. During the breeding season of 2003, one of the translocated birds was seen to have returned to Selvagem Grande, indicating that populations on the two islands were not isolated.

\section{Monitoring of vegetation and sensitive non- target species.}

\section{Vegetation}

Fig. 2 shows the average number of plant species found in the study quadrats between 2002 (pre-eradication) and 2005 (post-eradication). The average number of plant species found in the quadrats increased gradually between 2002 and 2005, from an average of 3.8 to 7.1, becoming significantly higher in 2005 (Wilcoxon test for matched pairs: $Z=-1.97 ; P<0,05)$.

Fig. 3 presents the average groundcover found in the study quadrats between 2002 (pre-eradication) and 2005 (post-eradication). Average groundcover increased gradually between 2002 and 2005 from 53 to $64 \%$, but the difference was not statistically significant (Wilcoxon test for matched pairs), probably because of the high level of between-quadrat variability.

\section{Invertebrates}

In general, the diversity and abundance of invertebrates in the samples increased during the post-eradication study period. Sample identification to species level is still ongoing, but for the purpose of monitoring the effects of the eradication program, data related to one order (Coleoptera) were used. Fig. 4 shows the number of individuals belonging to the four more common families of Coleoptera present in the samples.

All the families showed a general increase in the number of individuals captured after the mouse and rabbit eradication, although with high variability. Numbers of Curculionidae decreased in one year; however, significant increasing trends were found for the families Tenebrionidae (Friedman test: $X^{2}=13.00$; degrees of freedom $=3 ; P>0.05$ ) and Carabidae (Friedman test: $X^{2}=8.26$; degrees of free-

Table 2 The amounts of manpower used in man-days during the project on the principle actions of preparation, baiting and monitoring of effects (Further details of each of these actions are provided in the methods section of the paper)

\begin{tabular}{lc}
\hline Type of operations & Man-days \\
\hline Preparation: (including monitoring of target and non-target species before bait applications) & 555 \\
Bait laying: Phase 1 and 2 & 750 \\
Bait laying: Phase 3 & 550 \\
Monitoring: Rabbits and mice & 520 \\
Monitoring of non target species after bait laying operations and mitigation actions & 255 \\
\hline
\end{tabular}


dom $=3 ; P>0.05)$.

\section{Berthelot's pipit}

Fig. 5 shows the count data during the breeding season of Berthelot's pipit found in each of the transects carried out just before and during the baiting operations in 2002 and every breeding season thereafter.

During the 2002 baiting operations the number of birds dropped dramatically in all the areas surveyed. The average relative index found after bait laying operations is significantly lower than before $\left(U_{20,28}=97.5 ; P<0.001\right)$. However, during the 2003 breeding period that immediately followed the baiting program, the population recovered and returned to the numbers that had been observed before the project started. During the period 2003 to 2005, the population showed a further twofold significant increase $\left(U_{8,12}=0 ; P<0.001\right)$.

\section{Geckos}

Fig. 6 shows the densities of geckos located before and after the baiting operations in 2002 and the subsequent years until 2005.

The number of geckos before and after bait laying operations of 2002 was very similar and showed no significant difference (Wilcoxon test for matched pairs $Z=-0$. $347 ; P>0.05$ ), indicating that the baiting program appeared to have had no significant effect on the gecko population. However, the population index increased significantly between 2002 and 2005 (Friedman test $X^{2}=22.90$; degrees of freedom $=3 ; P<0.05$ ).

\section{DISCUSSION}

\section{Baiting operations and post-treatment monitoring}

Evidence of rabbit activity ceased within two weeks of the end of the first bait application from open bait stations, suggesting that in this arid environment the method of bait dispersion was very effective. Evidence of mouse activity continued for approximately six months after the main period of baiting, particularly in two areas where thorough bait application was difficult. In the first of these, we had been unwilling to risk trampling the sandy area because it contained breeding burrows recently vacated by white-faced storm petrels. These burrows presumably contained a quantity of edible detritus, such as dead petrel chicks and food scraps. That, and the fact that the area could not be baited thoroughly, probably delayed some mice finding and taking sufficient bait. Elsewhere, a large area of boulders was also difficult to bait with Pestoff 20R, and the smaller Vertox pellets and 5-g Klerat wax blocks were used there.

Monitoring the island for signs of rabbit activity was comparatively easy because of the relatively low density of vegetation cover and the large size of the target species. It was, therefore, with a high degree of confidence that we considered the island to have been free of rabbits by the middle of September 2002. However, it is virtually impossible in practice to monitor mouse activity to distinguish between a very low population level and a complete absence of mice (i.e. successful eradication). This was particularly the case on Selvagem Grande because of the dissected nature of the terrain and the inaccessibility of some areas (e.g. cliffs). Nevertheless, it was considered necessary to monitor the island frequently for areas of mouse activity and we were able to detect mouse gnawing on
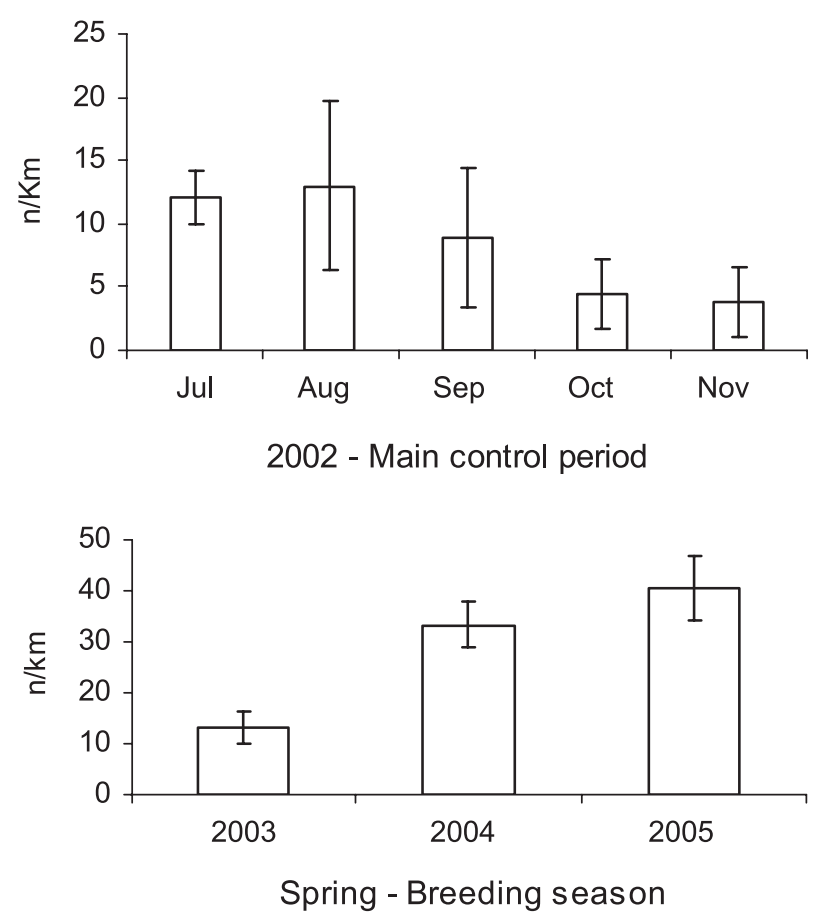

Figure 5 Results of counts of the numbers of Berthelot's pipit (Anthus b. betheloti) observed on four $800 \mathrm{~m}$ long transects on Selvagem Grande. Histograms show the mean numbers of birds per $\mathrm{km}$ of monitoring transect, with standard deviations, (a) during the period July to November 2002, the main period of bait application, and (b) in the spring of the three years following the eradication program. The number of birds present decreased significantly during the baiting program. However, numbers recovered to previous levels the following year (2003) and showed a significant increase in subsequent years. 
carrot and wax block baits successfully, even though it was occasionally masked by nibbling by insects, molluscs and reptiles. Rather than this intensive monitoring, an alternative option adopted by many who attempt island eradication of mice is simply to wait some time after the main control operation and to see whether mouse populations recover (K. G. Broome personal communication). However, had we adopted that approach and "saved" considerable resources, the small hot spots of remaining mice would probably not have been identified and the eradication would have failed. We consider that the mouse eradication program would have been even more difficult, or even impossible, had a low-level mouse population survived into the subsequent vegetation seeding season, because there would then have been a superabundance of natural food to compete with the poison bait.

Failure to find evidence of mice and rabbits after two and a half years of intensive field work gave us sufficient confidence to declare a successful eradication of both species from Selvagem Grande at the end of July 2005.

The remoteness and topographical features of Selvagem Grande were by far the most important constraints during this program. The fact that all the bait-laying operations had to be done by hand represented a considerable commitment of man-power. Although this involved the redeployment of full-time staff of the Natural Park Service of Madeira, there was a significant consequent impact on other conservation operations. An alternative strategy for bait laying would have been aerial application. However, the cost of shipping a suitable helicopter and pilot from mainland Europe, together with its associated infrastructure, would have been relatively expensive in cash terms, especially considering the risks of poor weather in the eastern Atlantic. The overall cost of the program (approximately 400000 euros) was somewhat higher than that of similar eradication projects conducted elsewhere, probably because Selvagem Grande is one of the largest islands from which mice have been eradicated using the labor-intensive method of hand baiting (see Martins et al. 2006).

\section{Ecosystem response}

Our findings showed that there was a positive response of several components of the ecosystem to the eradication program (see also Oliveira et al. 2003).

Monitoring results indicated that the vegetation had responded well to the absence of rabbits and mice. The consistent increase in the number of plant species present in the study sites was a clear indicator of vegetation recovery. However, in two of these sites the number of plant species decreased due to the saturation cover caused by the presence of Solanum lycopersicum (Linnaeus), a potentially invasive plant that exploded after the removal of mice and rabbits. This aspect of the program will be carefully monitored, and possibly managed, in the future. The rapid expansion of two invasive plants (Phalaris aquatica (Linnaeus, 1961) and Ageratina adenophora (Spreng.) King \& H.E. Robins after the eradication of rabbits in Deserta Grande required the implementation of a management plan to limit their uncontrolled spread (Oliveira 2007 unpublished data).

The fluctuation in percentage groundcover in monitoring quadrats was explained by the fact that, numerically, most of the vegetation of Selvagem Grande comprises annuals and is, therefore, greatly affected by rainfall patterns. Another factor accounting for this fluctuation
Figure 6 Results of counts of the numbers of geckos (Tarentola bischoffi) in 15 $100 \times 100 \mathrm{~m}$ quadrats distributed across Selvagem Grande. Histograms show the mean numbers of individuals per ha, with standard deviations. The numbers found in July and November 2002 (i.e. before and immediately after the main baiting period) did not differ significantly. However, the numbers of geckos found increased significantly between 2002 and 2005.

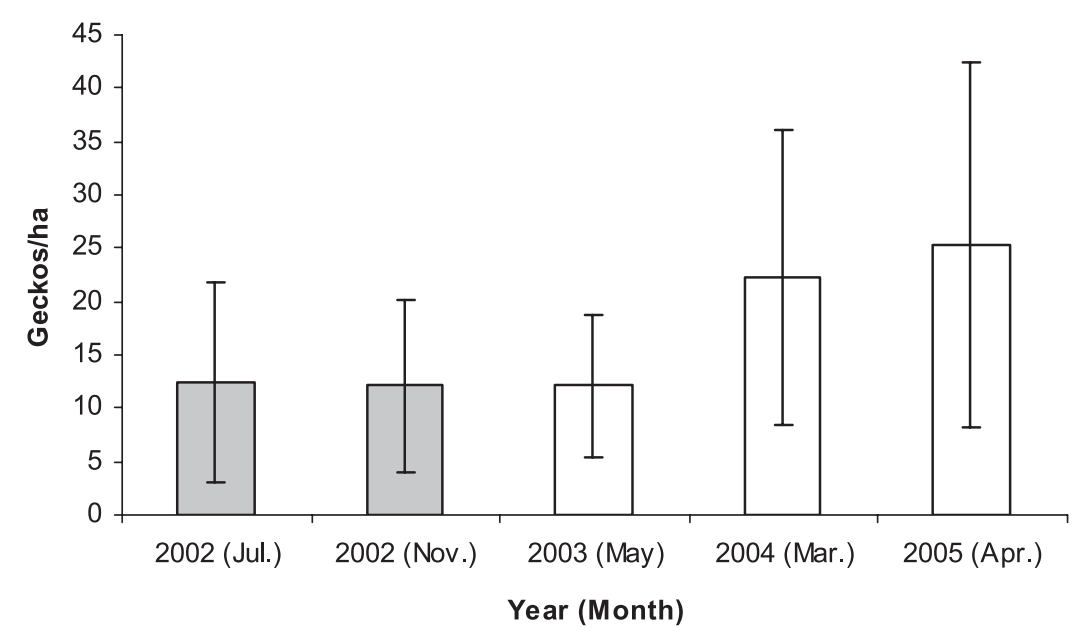

(C) 2010 ISZS, Blackwell Publishing and IOZ/CAS 
was the control and eradication of Nicotiana glauca that started in 2001 and was still ongoing in 2005.

Throughout the island, endemic plants such as Monanthes lowei (Paiva) P. Pérez \& J. R. Acebes Ginovés increased both in terms of abundance and groundcover. This also occurred with other important indigenous species and Macaronesian endemics, such as Centaurea melitensis (L.), Chenopodium coronopus Moquin, Lycopersicum esculentum Mill, Schizogyne sericea (L.f.) DC, Spergularia fallax Lowe and Anagalis arvensis L.. Moreover, a further 4 species (Fumaria montana (J. Schimidt), Emex spinosa (L.) Campd., Limonium papillatum Kuntze and Misopates selvagensis (D. Sutton), that were thought to be locally extinct, were recently recorded on Selvagem Grande. Further systematic studies are being carried out and new species to the island (and possibly new to science) are now being described (e.g. four species belonging to the family Poaceae).

The relative abundance of the four families of Coleoptera, which are monitored in detail, have increased on the island and field observations indicate that this is also true for other invertebrate taxa. The higher abundance of insects was most probably linked to the fact that most of them live in direct association with plants (or predate herbivorous insects), which in turn were also more abundant. The lack of statistically significant differences was most probably due to the fact that the sample set was small and very different habitats were sampled. The number of individuals for one family captured ranged between 0 and 502 in the same year in different quadrats so the dataset had a very high degree of variability.

Further systematic studies are in progress and new species of invertebrates to the island will be described. This might, of course, relate either to the lack of rigorous surveys in the past, recent invasion, the increased relative abundance of these species since the mammal eradication or these factors working in conjunction. However, seven new additions to the spider fauna have already been reported, and possibly two species new to science have been found (Crespo et al. 2006). Concerning the aphid fauna (Homoptera, Aphidoidea), four species have been identified that are new recordings for the Salvage islands (Pita et al. 2007).

Merton (1987) found no adverse impact of anticoagulant bait application on lizard populations and we could not see any obvious impact on them on Selvagem Grande, although they were not monitored intensively because they were not considered to be at significant risk (Bell 2001). The fact that gecko population indices were not affected during the baiting operations was an important finding, suggesting that any insect prey that ate bait did not subsequently affect the predatory gecko. The population increase was most probably related to a combination of the release of the predation pressure of mice on eggs and young and the increased insect food availability.

Although baiting operations had a negative impact on the Berthelot's pipits, as they closely followed the baiting teams and were seen to feed on bait, it was not possible to explain to what extent the provision of vitamin $\mathrm{K}_{2}$ for drinking aided their survival. Although many ringed birds were seen regularly using these structures, it was not possible to determine what proportion of the population adopted this behavior nor, because of lack of technical resources, if they consumed an effective dose of the antidote. However, the pipit population recovered remarkably quickly over the following years. There are a number of possible explanations for this. Berthelot's pipit is a ground nesting bird so it is probable that rabbit disturbance and mouse predation on nests, eggs and chicks were having some limiting effect on their population. However, being an essentially insectivorous bird, the higher availability of insects post-eradication probably also had a positive impact on body condition and breeding success.

Because of the limited number of staff available, seabird populations were not directly monitored by the present authors. However, a recent study (Zino et al. 2008) has shown that the breeding success of Cory's shearwater is now consistently higher than before the mouse and rabbit eradication program occurred. In fact, a notable rise in the number of chicks fledged was apparent during the year of the eradication (i.e. breeding season 2002) and, because the shearwater chicks did not hatch until after the principle baiting operation was completed, it appears that whatever detrimental impact the alien vertebrates had exerted was applied to the chicks rather than to earlier stages of the reproductive cycle. This also shows that all the intensive field operations carried out in 2002 had no longterm negative impact on the birds' breeding.

\section{Subsequent quarantine measures}

Stringent quarantine measures are rigorously implemented to reduce the chances of reinvasion of the island by mice. Visiting boats are forbidden to pass any ropes to land and all the food and equipment of the Natural Park Service of Madeira wardens, or other visitors, are transported in sealed plastic containers. Additionally, during the summer, when the number of visits to the island increases, a cordon of tubes with bait is placed around the only official anchoring place of the island and these are inspected regularly. 


\section{ACKNOWLEDGMENTS}

The field coordination operated by Manuel José and the dedication, enthusiasm and altruism of Filipe Viveiros, Jaques da Mata, João Paulo, João Gomes, Luis Ferro, Manuel Lourenço, Martinho Pires, Pedro Gouveia and Ricardo Cabral was crucial to the success of bait laying operations. Isamberto Silva and Maurilio Freitas were responsible for much of the post-eradication monitoring program. The contribution of the volunteers Sónia Camacho and David Teixeira was greatly appreciated. The personal and institutional support of Susana Fontinha, Director of the Parque Natural da Madeira, and the efforts of the rest of the staff of the Parque Natural da Madeira, who had to deal with the shortage of personnel that this project implied is not forgotten. Bill Simmons gave valuable advice on rabbit-with-mouse poison bait components and baiting. Sorex provided Talon and Klerat wax block bait used for the over-winter period. Francis Zino gave wise advice during the earlier stages of the project and promoted, on the behalf of the Natural Park Service of Madeira, the first visit that Roger Trout made to the island.

\section{REFERENCES}

Arnold EN, Arribas O, Carranza S (2007). Systematics of the Palaearctic and Oriental lizard tribe Lacertini (Squamata: Lacertidae: Lacertinae), with descriptions of eight new genera. Zootaxa 1430, 1-86.

Atkinson IAE (1985). The spread of commensal species of Rattus to oceanic islands and their effects on island avifaunas. In: PJ Moors, ed. Conservation of Island Birds. ICBP Technical Publication No. 3. Cambridge, England, International Council for Bird Preservation, pp. 35-81.

Bailey AM (1956). Birds of Midway and Laysan Islands (Museum Pictorial No. 12). Denver Museum of Natural History, Denver, Colorado, USA.

Bell B (2001). Removal of rabbits from Deserta Grand island, Madeira Archipelago. Arquipélago, Life and Marine Sciences Supplement 2, 115-7.

Blight LK, Ryder JL, Bertram DF (1999). Predation of rhinoceros auklet eggs by native population of Peromyscus. The Condor 101, 871-6.

BirdLife International (2007). Species factsheet: Pterodroma feae. [Cited 26 Sep 2007.] Available from URL: http:// www.birdlife.org

Brown WY (1975). Rabbit destruction of tern eggs. The Auk 91, 840-1.

Burfield I, van Bommel F (2004). Birds in Europe: Popula- tion Estimates, Trends and Conservation Status. Birdlife Conservation Series no. 12. Birdlife International, Cambridge, UK.

Campos R, Granadeiro P (1999). Breeding biology of the White-Faced Storm Petrel, Pelagodroma marina, on Selvagem Grande Island, North-East Atlantic. Waterbirds 22, 199-207.

Costa LT, Nunes M, Geraldes P, Costa H (2003). Zonas importantes paras as aves em Portugal (Important Bird Areas in Portugal). Portuguese Society for Bird Study. Lisbon. 160 pp. (In Portuguese.)

Courchamp F, Chapuis J-L, Pascal M (2003). Mammal invaders on islands: impact, control and control impact. Biological Review 78, 347-83.

Crespo L, Cardoso P, Menezes D, Silva I (2006). Contribution to the knowledge of spiders (Araneae) in the Salvage Islands. Poster presented at 23rd Colloquium of Arachnology, 9-10 May, Sevilla, Spain.

Cuthbert R, Hilton G (2004). Introduced House mice Mus musculus: a significant predator of threatened and endemic birds on Gough Island, South Atlantic Ocean? Biological Conservation 117, 483-9.

Drever MC, Blight LK, Hobson KA, Bertram DF (2000). Predation on seabird eggs by Keen's mice (Peromyscus keeni): using stable isotopes to decipher the diet of a terrestrial omnivore on a remote offshore island. Canadian Journal of Zoology 78, 2010-8.

Ely CA, Clapp RB (1973). The natural history of Laysan Island, Northwestern Hawaiian Islands. Atoll Research Bulletin 171, xi 361 pp.

European Commission (2007) Natural Network. [Cited 5 Dec 2007.] Available from URL: http://ec.europa.eu/environment/nature/natura2000/index_en.htm.

European Economic Community (1979). Council Directive of 2 April 1979 on the Conservation of Wild Birds (79/ 409/EEC). Official Journal of the European Communities $L$ 103, $1-18$.

Florentine SK, Westbrooke ME (2005). Invasion of the noxious weed Nicotiana glauca $\mathrm{R}$. Graham after an episodic flooding event in the arid zone of Australia. Journal of Arid Environment 60, 531-45.

Flux JEC (1994). World distribution of the rabbit. In: Thompson HV, King C, eds. The European Rabbit: The History and Biology of a Successful Coloniser. Oxford Science Publications, Oxford, pp. 8-17.

Flux JEC, Fullager PJ (1992). World distribution of the rabbit (Oryctolagus cuniculus) on islands. Mammal Review 22, 151-205. 
Granadeiro JP, Dias MP, Rebelo R, Santos CD, Catry P (2006). Numbers and populations trends of Cory's Shearwater (Calonectris diomedea) at Salvagem Grande, Northeast Atlantic. Waterbirds 29, 56-60.

Gray A, Pelembe T, Stroud S (2005). The conservation of the endemic vascular flora of Ascension Island and threats from alien species. Oryx 39, 449-53.

Grimmett RF, Jones T, eds (1989). Important Bird Areas in Europe. International Technical Publication no. 9 Council for Bird Preservation, Cambridge, UK.

Igual JM, Forero MG, Gomez T, Orueta JF, Oro D (2006). Rat control and breeding performance in Cory's shearwater (Calonectris diomedea): effects of poisoning effort and habitat features. Animal Conservation 9, 59-65.

Lockley RM (1976). The Private Life of the Rabbit: An Account of the Life History and Social Behaviour. Longmans, London, UK.

Long JL (2003). Introduced Mammals of the World: Their History, Distribution and Influence. CABI Publishing, Wallingford, UK.

Lowe S, Browne M, Boudjelas S, De Poorter M (2000). 100 of the World's Worst Invasive Alien Species: A selection from the Global Invasive Species Database. The Invasive Species Specialist Group (ISSG), Species Survival Commission (SSC) of the World Conservation Union (IUCN), Auckland, New Zealand.

Martins TFL, de L Brooke M, Hilton GM, Farnsworth F, Gould J, Pain DJ (2006). Costing eradications of alien mammals from islands. Animal Conservation 9, 439-44.

Menezes D, Gouveia L, Domingues M, Jardim N, Fontinha S (2004). Selvagens Islands. Parque Natural da Madeira. Funchal, Madeira, Portugal.

Merton DV (1987). Eradication of rabbits from Round Island, Mauritius. Dodo 24, 19-44.

Neves HC (1995). Analysis of the vegetation of the Ilhéu de Fora - Selvagens Islands. Boletim Museu Municipal do Funchal 4, 505-10.

Oliveira P, Menezes D (2004). Birds of the Archipelago of Madeira. Madeira and Madeira, Funchal, Madeira, Portugal.

Oliveira P, Trout RC, Menezes D, Geraldes P, Buckle AP, Domingues M (2003). Recuperaçâo Dos Habitates Terrestres Da Selvagem Grande. In: Rodrigues-luengo $\mathrm{JL}$, Ed. Control de vertebradors invasivores en islas de Espana y Portugal. Consejeria de Medio Ambiente y Ordenaccion territorial del Gobierno de Canarias, Tenerife, p. 60. (In Portuguese.)

Pita MT, Silva I, Menezes D, Ilharco FA (2007). On the aphid fauna (Homoptera, Aphidoidea) of the Salvage Islands, with new records to Selvagem Grande. Revista de la Academia Canaria de Ciencias 18, pp. 111-6.

Press JR, Short MJ (1994). Flora of Madeira. Natural History Museum, Her Majesty's Stationery Office, London.

Sanz-Elorza M, Dana ED, Sobrino E (2001). Aproximación al listado de plantas alóctonas invasoras reales y potenciales en Espana. Lazaroa 22, 121-31.

Sheail J (1971). Rabbits and Their History. David and Charles, Newton Abbot, UK.

Veitch CR, Clout MN, eds. (2002). Turning the Tide: The Eradication of Invasive Species. IUCN SSC Invasive Species Specialist Group. IUCN, Gland, Switzerland and Cambridge, UK.

Wanless RM, Angel A, Cuthbert RJ, Hilton GM, Ryan PG (2007). Can predation by invasive mice drive seabird extinctions? Biology Letters 3, 241-4.

Zino F, Hounsome MV, Buckle AP, Biscoito M (2008). Was the removal of Rabbits Oryctolagus cuniculus and House Mice Mus musculus from Selvagem Grande beneficial to the breeding productivity of Cory's Shearwater Calonectris diomedea borealis? Oryx 42, 151-3. 